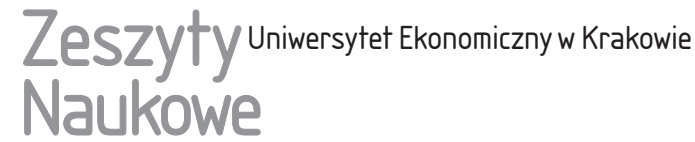

\section{Tradycyjne i nowoczesne formy budowania sieci bankowej w Polsce}

\section{Streszczenie}

Celem artykułu jest analiza tendencji dotyczących tradycyjnych i nowoczesnych metod budowania sieci bankowej w Polsce. Rozwój technologii, nowoczesnych kanałów dostępu do usług bankowych, jak również propagowanie obrotu bezgotówkowego w Polsce sprzyjają powstawaniu infrastruktury sytemu bankowego nastawionej na ograniczanie kosztów prowadzenia działalności oraz innowacjom finansowym (FinTech). Banki w Polsce i na całym świecie czeka zmiana strategii funkcjonowania na rynku (zwłaszcza w zakresie sprzedaży usług bankowych). Zmieniające się preferencje klientów wymuszają procesy dostosowawcze, które w znaczny sposób wpływają na organizację sieci bankowej. W najbliższym czasie ograniczana będzie liczba własnych oddziałów bankowych i bankomatów. Wynika to przede wszystkim z zapotrzebowania rynku (konsumentów), jak również ograniczania kosztów działalności bankowej. Rozwój rynku kart płatniczych i nowoczesnych form płatności umożliwia bankom dywersyfikację kanałów dystrybucji usług bankowych. Zmieniające się regulacje (m.in. dyrektywa PSDII) stwarzają również szerokie możliwości rozwoju innowacji finansowych oferowanych przez rynek FinTech, który będzie w znacznym stopniu kreował sieć bankową w Polsce w najbliższym czasie.

Słowa kluczowe: sieć bankowa, innowacje finansowe, karty płatnicze, sektor FinTech. Klasyfikacja JEL: G24. 


\section{Wprowadzenie}

Tradycyjnie rozumiana sieć bankowa opiera się na rozlokowaniu oddziałów własnych i placówek partnerskich banków w poszczególnych miejscach. Niemniej jednak rozwój technologii, nowoczesnych kanałów dostępu do usług bankowych, propagowanie obrotu bezgotówkowego w Polsce sprzyjają rozwojowi nie tylko infrastruktury sytemu bankowego zorientowanej na ograniczanie kosztów prowadzenia działalności, ale również innowacjom finansowym (FinTech). W artykule sieć bankowa rozumiana jest w tradycyjny sposób (stacjonarny) jako sieć oddziałów i placówek partnerskich, jak i nowoczesny - przez rozwój bankowości elektronicznej, rozwój funkcjonalności urządzeń (np. bankomatów) oraz rozwój rynku FinTech. Celem artykułu jest analiza tendencji rozwoju sieci bankowej w Polsce oraz tradycyjnych i nowoczesnych metod jej budowania.

\section{Sieć bankowa jako kanał dystrybucji usług bankowych}

Efektywna sieć dystrybucji usług bankowych stosowanych w instytucjach finansowych jest jednym z kluczowych elementów prowadzonego przez banki marketingu. Znaczny wpływ na ewolucję metod budowania sieci bankowej danej instytucji mają zachowania i preferencje konsumentów - zwłaszcza gospodarstw domowych. Rozwój finansów osobistych i finansów gospodarstw domowych, które obejmują ogół procesów związanych z pozyskiwaniem, gromadzeniem i wydatkowaniem środków finansowych przez osoby fizyczne/gospodarstwa domowe (Finanse osobiste... 2016, s. 24), zmusza banki do działań odpowiadających preferencjom i potrzebom klientów. Rozwój terminologii związanej m.in. z finansami rodziny prowadzi nie tylko do rozwoju tradycyjnych narzędzi używanych w mikroekonomii, ale też zmiany tradycyjnego wyjaśniania zachowań konsumentów (Flejterski 2007, s. 94).

Ze względu na kryterium podmiotowe można wyróżnić dwa podstawowe sposoby dystrybucji produktów i usług na rynku: bezpośredni i pośredni (Boguski 2016, s. 112). Kanały dystrybucji funkcjonujące w bankach nie tylko zaspokajają popyt konsumentów, ale również mają na celu go stymulować. Klienci banków z uwagi na różne uwarunkowania są skłonni do podejmowania decyzji mających zaspokoić ich potrzeby finansowe (Krzyścin 2013, s. 41). Wśród licznych czynników wpływających na zachowania nabywców można wyróżnić (Grzegorczyk, Krawiec i Sibińska 2010, s. 8):

- czynniki wewnętrzne (psychologiczne, ekonomiczne, demograficzne, geograficzne), 
- czynniki zewnętrzne (technologia, regulacje prawne, poziom rozwoju gospodarczego, sytuację rynkową, produkt bankowy).

W systemie bankowym największy wpływ na zachowania konsumentów mają czynniki zewnętrzne. Dynamiczny rozwój technologii w znaczący sposób wpływa na ewolucję kanałów dystrybucji usług bankowych, np. przez bankowość elektroniczną. Regulacje prawne i działania regulatorów rynku sugerują propagowanie obrotu bezgotówkowego w Polsce. Rozwój gospodarczy kraju, zmiany stylu życia, jak i ewolucja usług bankowych sprzyjają ewolucji rynku innowacji finansowych. Kluczowe jest też całkowicie nowe podejście do analizy rynków nowych technologii. Określa się je jako rynki szybko rozwijające się, na których ciągle pojawiają się innowacje i dużą rolę odgrywają prognozy rozwoju rynku (Mirabile i in. 2015). Banki bardzo często decydują się na współpracę np. z operatorami komórkowymi, tworząc platformy zakupowe (Szpringer 2017, s. 50). W Polsce alianse strategiczne pomiędzy bankami a operatorami komórkowymi są widoczne m.in. we współpracy:

- mBanku SA z siecią Orange (Orange Finanse produkty bankowe dostarcza mBank SA),

- Alior Banku SA z siecią T-Mobile (T-Mobile usługi finansowe dostarcza Alior Bank SA),

- Plus Banku SA z siecią Plus.

Jeśli chodzi o rozwój technologii, banki mogą budować swoją sieć, mając do wyboru kilka strategii. Mogą one (Costa i in. 2015):

- tworzyć w pełni cyfrowy bank uniwersalny,

- oferować efektywne kosztowo operacje back-office, natomiast usługi bankowe sprzedawać pod inną marką (np. sieci komórkowych),

- świadczyć usługi niszy rynkowej,

- być punktem kontaktu dla klientów poszukujących zarówno usług bankowych, jak i powiązanych usług w innych segmentach rynku.

Sytuacja na rynku finansowym, zwłaszcza przez jego deregulację i liberalizację przed kryzysem finansowym, doprowadziła do ogromnego wzrostu sektora finansowego w gospodarce. Gwałtowny rozwój sektora finansowego w krajach wysoko rozwiniętych był początkowo traktowany jako kolejny etap rozwoju gospodarki (Liberska 2016, s. 221). Okazało się jednak, że jego wzrost prowadził do coraz większego zagrożenia dla stabilnego rozwoju gospodarczego i stanowił źródło finansowych kryzysów (Dembinski 2011). Działania te w połączeniu ze zmieniającymi się preferencjami konsumentów prowadzą do dynamicznego rozwoju sieci dystrybucji usług bankowych. Dlatego też coraz większą uwagę poświęca się zarządzaniu ryzykiem bankowym. W prawie bankowym obowiązującym w Polsce podkreślono istotę sytemu zarządzania w banku (Ustawa z dnia 29 sierpnia 1997 r. ..., art. 9). Zaznaczono, że system zarządzania stanowi zbiór 
zasad i mechanizmów odnoszących się do procesów decyzyjnych zachodzących w banku oraz do oceny prowadzonej działalności bankowej. W ramach systemu zarządzania w banku wyróżniono co najmniej system zarządzania ryzykiem oraz system kontroli wewnętrznej.

Istotne jest to, że tych dwóch funkcji bank nie może oddać w outsourcing, ponieważ ponosi za nie pełną odpowiedzialność (m.in. musi wskazać, który z członków zarządu jest odpowiedzialny za zarządzanie ryzykiem) (Zarzqdzanie ryzykiem... 2012, s. 66). Brak możliwości oddawania w outsourcing zarządzania ryzykiem w banku jest kluczowy w budowaniu nowoczesnej sieci bankowej.

Dla budowania sieci bankowej istotne są kanały dystrybucji usług bankowych, wśród których można wyróżnić:

- kanały bezpośrednie (np. przez sprzedaż produktów w oddziałach banku twarzą w twarz, czy też przez sprzedaż usług z wykorzystaniem bankowości elektronicznej, czyli w formie sprzedaży produktów na odległość, np. bankowość mobilna),

- kanały pośrednie (np. sprzedaż produktów przez agencje i dealerów).

Budowa sieci placówek bankowych (zob. rys 1) i rozwój sieci dystrybucji usług bankowych, np. przez bankowość mobilną, są w całości nadzorowane przez bank (w procesie zarządzania ryzykiem bankowym).

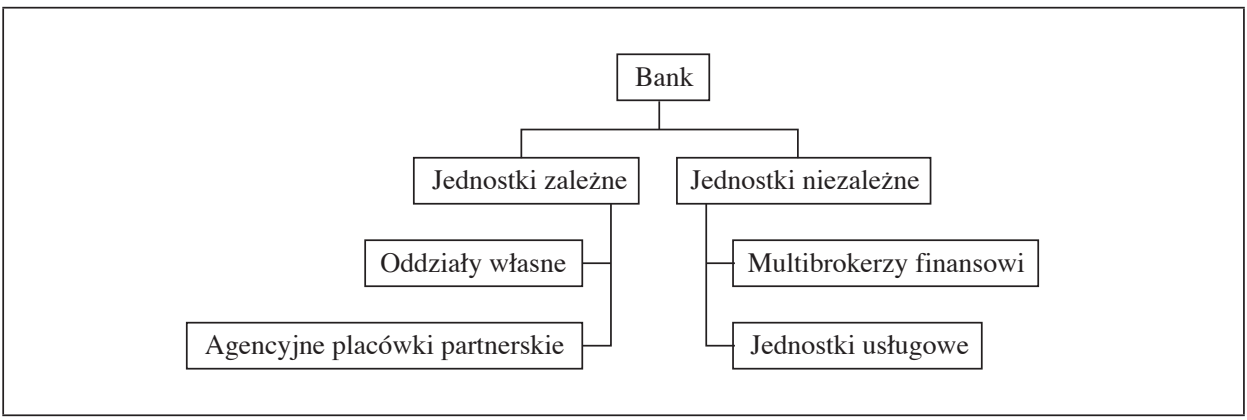

Rys. 1. Przykład budowy sieci placówek bankowych

Źródło: (Bank i agent... 2017, s. 102).

Rozwój sieci bankowej wpływa w istotny sposób na poziom bezpieczeństwa transakcji finansowych. Zdefiniowanie poziomu bezpieczeństwa finansowego jest trudnym zadaniem, niemniej jednak można je określić jako brak zagrożeń wywołujących różnego rodzaju ryzyko w sferze finansów publicznych, finansów przedsiębiorstw, finansów banków, finansów osobistych gospodarstw domowych, ubezpieczeń (Elementy nauki... 2007, s. 15). Bezpieczeństwo instytucji finansowych oznacza ich niezakłócone funkcjonowanie, przejawiające się przede wszystkim w dobrej kondycji ekonomiczno-finansowej, ich wypłacalności i utrzymywaniu 
ryzyka działania w tzw. bezpiecznych granicach, co stwarza możliwości szybkiego reagowania na pojawiające się zagrożenia (Capiga 2015, s. 20). Bezpieczeństwo finansowe banków może być znacznie zwiększone w przypadku budowania sieci bankowej, jeśli głównym kryterium rozwoju tej sieci jest chęć sprzedaży jak największej liczby usług bankowych. Realizacja planów sprzedażowych przez liczne kanały dystrybucji (bezpośredniej lub pośredniej) czy też jednostki zależne i niezależne może istotnie wpływać na poziom zarządzania ryzykiem w banku. Komisja Nadzoru Finansowego w licznych dokumentach popierających rozwój innowacji finansowych (FinTech) poziom bezpieczeństwa stawia na pierwszym miejscu.

\section{Rozwój sieci bankowej w Polsce}

Liczba banków prowadzących działalność w Polsce w ostatnich latach maleje. Ma to związek m.in. z konsolidacją sektora bankowego, zwłaszcza banków komercyjnych, oraz nielicznymi upadkami banków spółdzielczych. Zmniejszanie się liczby podmiotów prowadzących działalność bankową w Polsce prowadzić może do ograniczenia tradycyjnej sieci dystrybucji usług bankowych. Czynnikami mogącymi mieć wpływ na ograniczenie stacjonarnej sieci bankowej w Polsce są:

- liczne fuzje i przejęcia (m.in. repolonizacja banków),

- regulacje bankowe (m.in. podatek bankowy oraz podwyższone wymogi kapitałowe),

- rozwój technologii (m.in. funkcjonalność urządzeń bankowych - bankomatów, biometrii),

- zmiana preferencji klientów bankowych (m.in. coraz częstsze korzystanie z bankowości elektronicznej),

- propagowanie obrotu bezgotówkowego przez regulatorów rynku.

Na rys. 2 przedstawiono stacjonarną sieć bankową w Polsce. Wśród podmiotów ją tworzących można wyróżnić: oddziały bankowe, przedstawicielstwa oraz filie i inne punkty obsługi klienta mogące pośredniczyć w sprzedaży usług bankowych. Od 2012 r. zauważalny jest znaczny spadek liczby oddziałów bankowych, które prowadzą obsługę klientów w Polsce. Pod koniec czerwca 2017 r. w Polsce funkcjonowało o 767 mniej oddziałów bankowych niż w 2012 r. Na spadek ten mogą mieć wpływ wymienione wyżej czynniki, a także strategie banków. Coraz częściej zakładają one sprzedaż usług bankowych przez elektroniczne kanały dostępu. Z pewnością ma na to wpływ odchodzenie od prowadzenia obrotu gotówkowego w oddziałach banków. W najbliższej przyszłości banki, aby ograniczyć koszty działalności w Polsce, mogą np. otwierać stoiska w galeriach handlowych i miejscach, gdzie gromadzą się ludzie, lub kioski bankowe - niewielkie powierzchniowo bezosobowe punkty obsługi klienta (przykładem jest wdrażana w USA strategia Wells Fargo). 


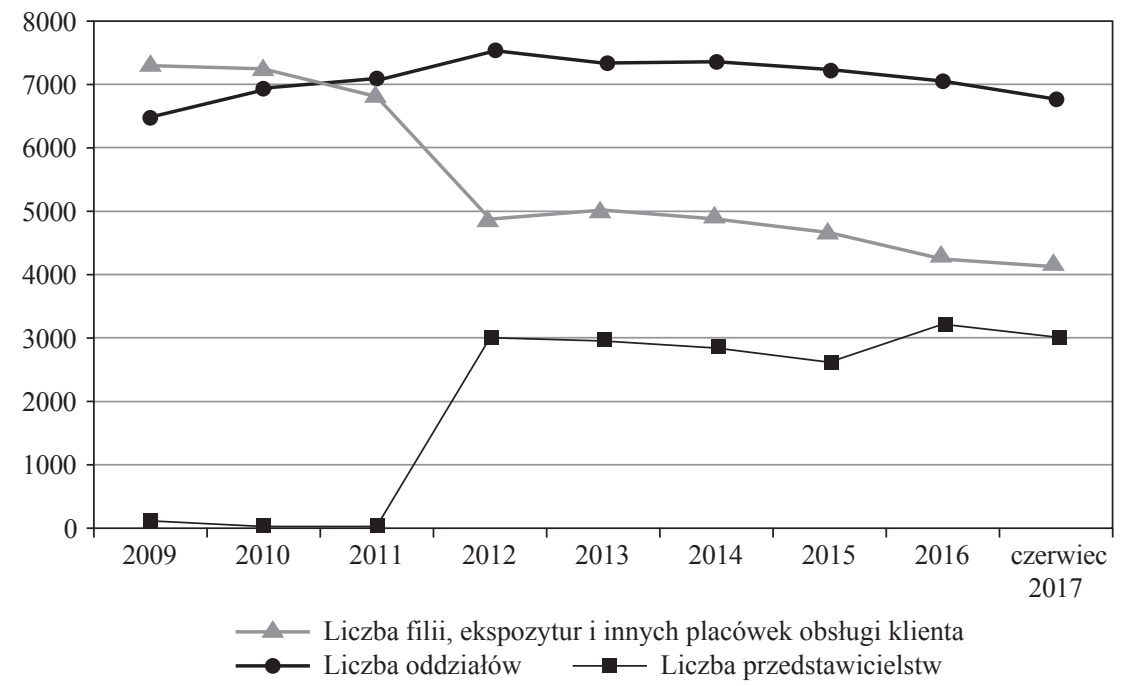

Rys. 2. Stacjonarna sieć bankowa w Polsce

Źródło: opracowanie własne na podstawie danych KNF.

Liczba filii, ekspozytur i innych placówek obsługi klienta jest w ostatnich latach znacznie ograniczana - pojawia się za to coraz więcej przedstawicielstw banków mogących świadczyć usługi bankowe. Warto zwrócić uwagę, że liczba filii, ekspozytur i innych placówek obsługi klienta była w latach 2009-2010 wyższa niż liczba oddziałów własnych banków prowadzących działalność w Polsce.

Rozwój sieci bankowej w postaci stacjonarnych punktów obsługi może być ograniczany przez rozwój innych elementów systemu bankowego. Niewątpliwie ma na to wpływ rozwój infrastruktury związanej z obrotem bezgotówkowym, np. rynku kart płatniczych. Na rys. 3 przedstawiono dane dotyczące liczby kart płatniczych w Polsce oraz poziom transakcji kartami płatniczymi w IV kwartale każdego analizowanego okresu. Liczba kart płatniczych w marcu 2017 r. przekroczyła 37,5 mln. Od 2010 r. w Polsce przybyło ponad 5,7 mln kart płatniczych. Oczywiście wzrost liczby kart płatniczych prowadzi do wzrostu liczby transakcji kartami, zaś różne działania regulatorów rynku bankowego w Polsce sprzyjają upowszechnianiu płatności kartami (np. wdrożenie w 2012 r. transakcji zbliżeniowych, do których potwierdzenie za pomocą kodu PIN nie jest konieczne. Aktualnie rozważana jest propozycja podwyższenia kwoty dla transakcji zbliżeniowych z 50 zł do 100 zł). 


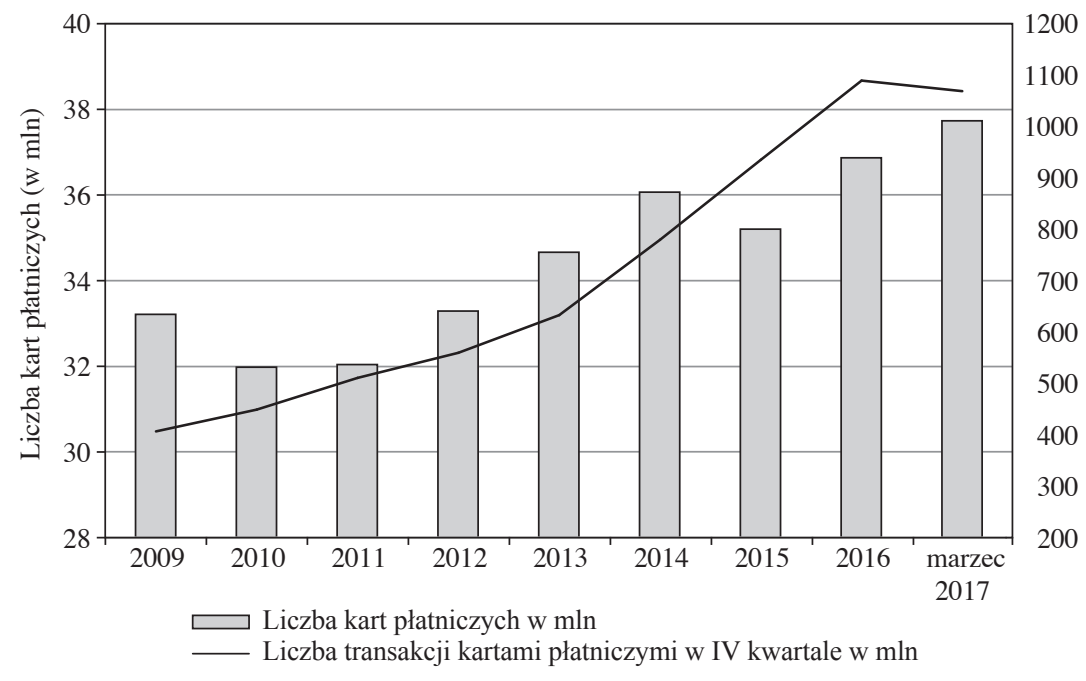

Rys. 3. Rynek kart płatniczych w Polsce

Źródło: opracowanie własne na podstawie danych NBP.

Dynamiczny rozwój rynku kart płatniczych (jak również całej infrastruktury systemu bankowego z tym związanej) oraz liczne działania regulatorów rynku na rzecz propagowania obrotu bezgotówkowego w Polsce (np. obniżenie opłaty interchange, wdrożenie terminali $\mathrm{w}$ administracji i na Poczcie Polskiej, popularyzacja płatności internetowych za pomocą kart płatniczych) powodują znaczny wzrost udziału transakcji bezgotówkowych dokonywanych z użyciem kart płatniczych (rys. 4). W 2009 r. spośród transakcji dokonywanych kartami płatniczymi transakcje gotówkowe (najczęściej wypłaty środków pieniężnych z bankomatów) stanowiły ok. $48 \%$ ogółu transakcji kartami płatniczymi. Zmiany preferencji konsumentów (m.in. na rzecz obrotu bezgotówkowego) doprowadziły do tego, że w marcu 2017 r. zaledwie 17\% ogółu transakcji kartami płatniczymi dokonywanych było gotówkowo.

Wśród transakcji gotówkowych dokonywanych kartami płatniczymi zdecydowaną większość stanowią wypłaty gotówki z bankomatów (rys. 5). W okresie od 2009 r. do marca 2017 r. nie było to mniej niż 90\%. Niemniej jednak zauważalna jest interesująca tendencja dotycząca wypłat środków pieniężnych w kasie banku i w sklepie. W 2009 r. zaledwie 0,1\% wypłat gotówkowych przy użyciu kart płatniczych stanowiły wypłaty w sklepach. Popularyzacja usługi cash back, większa liczba podmiotów mogących wypłacić środki pieniężne (np. sieć sklepów Żabka, stacje paliw Orlen) oraz podniesienie limitów wypłat środków pieniężnych 
prowadzą do coraz większego udziału wypłat pieniędzy w sklepach. Dlatego warto zwrócić uwagę na znaczny spadek udziału wypłat środków pieniężnych w kasie banku, co może potwierdzać tezę o odchodzeniu od obrotu gotówkowego w oddziałach bankowych w Polsce.

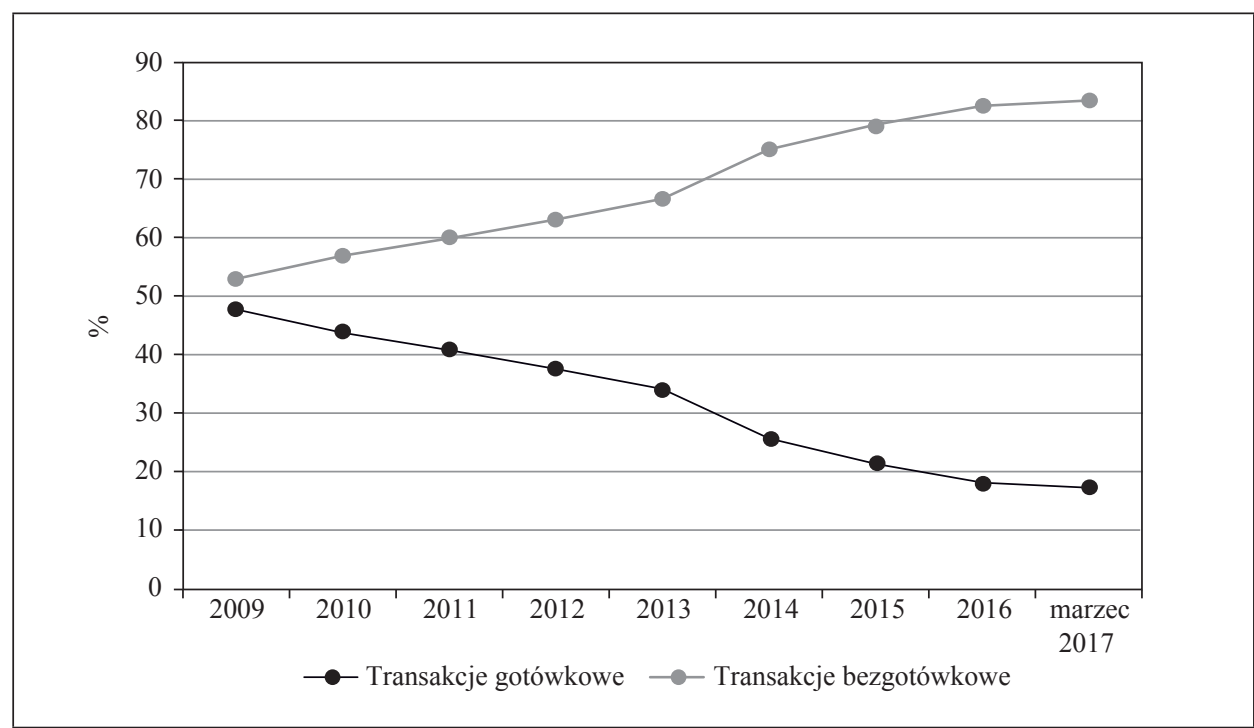

Rys. 4. Udział transakcji gotówkowych i bezgotówkowych dokonywanych kartami płatniczymi w Polsce

Źródło: opracowanie własne na podstawie danych NBP.

Rozwój transakcji bezgotówkowych w Polsce nie byłby możliwy bez rozwoju sieci bankowej w zakresie infrastruktury dla kart płatniczych i obsługi obrotu bezgotówkowego (rys. 6). W analizowanym okresie (2009-marzec 2017) najdynamiczniej rozwijała się sieć punktów przyjmujących wpłaty na rachunki oszczędnościowo-rozliczeniowe (ROR). Liczba tych punktów w 2009 r. wynosiła ok. 14 tys., zaś pod koniec 2016 r. było ich już ponad 40,5 tys. Wzrost widoczny był również w zakresie liczby terminali POS - liczba ta w analizowanym okresie wzrosła o 333 tys. Z pewnością wpływ na to miały działania regulatorów rynku (m.in. spadek opłaty interchange, montaż tego typu urządzeń w podmiotach administracji publicznej). Propagowanie w Polsce obrotu bezgotówkowego sprzyja również wzrostowi liczby bankomatów. Liczba tych urządzeń w analizowanym okresie wzrosła o ponad 8 tys.

Wzrost liczby bankomatów w Polsce może mieć istotne znaczenie, jeśli chodzi o sprostanie oczekiwaniom zgłaszanym przez konsumentów usług bankowych. 


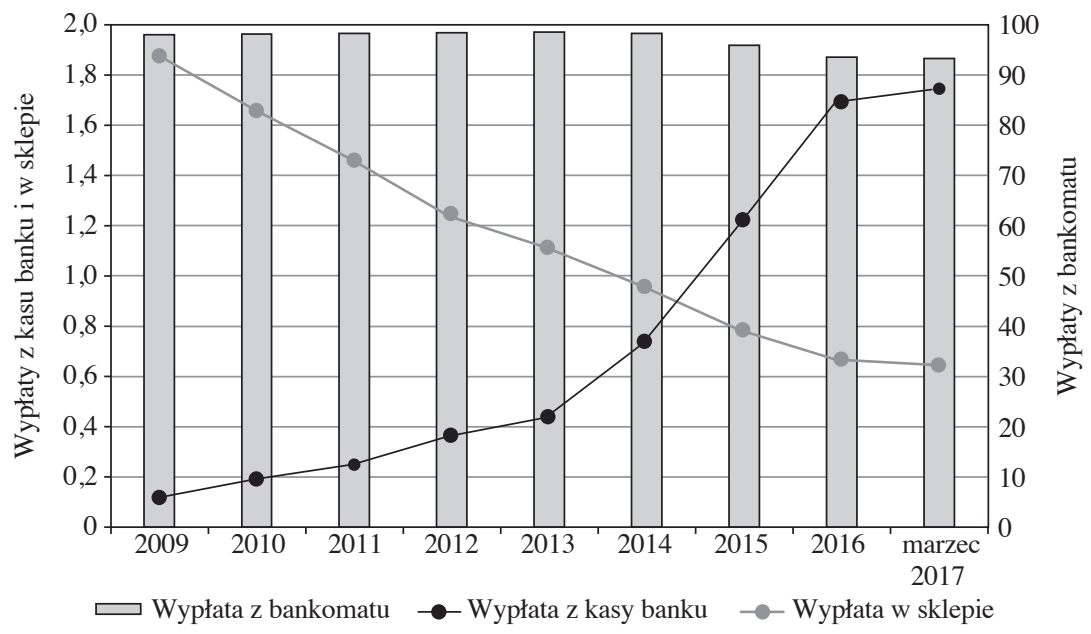

Rys. 5. Transakcje gotówkowe (udział wypłat z bankomatu, z kasy banku i w sklepie, w \%) Źródło: opracowanie własne na podstawie danych NBP.

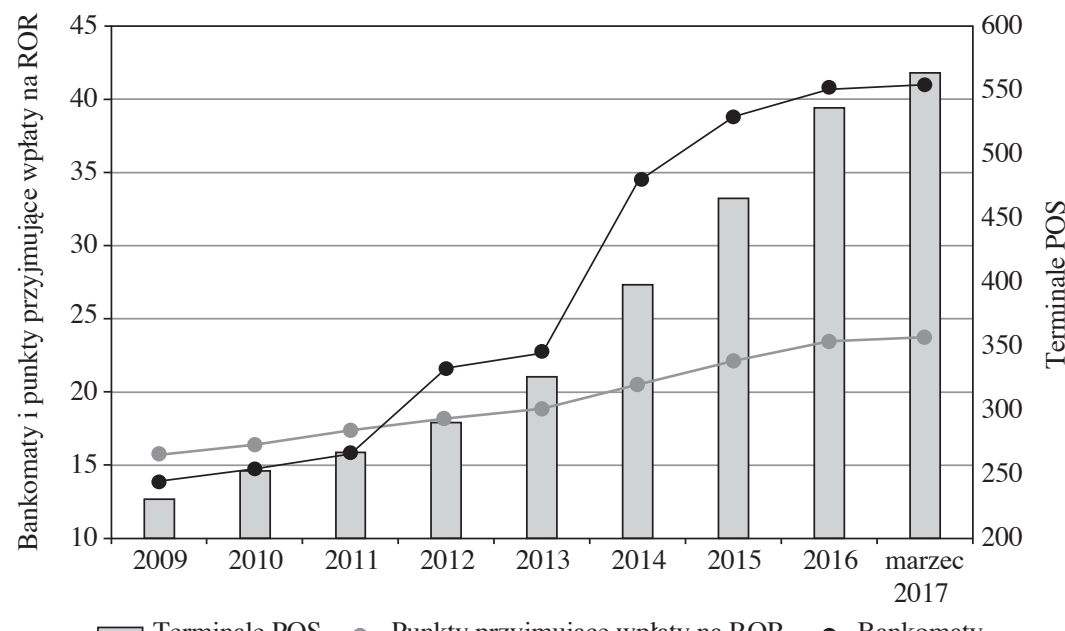

Rys. 6. Wybrane elementy infrastruktury sieci bankowej w Polsce (w tys.)

Źródło: opracowanie własne na podstawie danych KNF i NBP. 
Klienci banków chcą ograniczyć wizyty w tradycyjnych oddziałach bankowych. Dlatego też rozwój funkcjonalności bankomatów może znacząco ułatwić konsumentom dostęp do licznych usług bankowych oferowanych do tej pory w tradycyjnych oddziałach bankowych. W nowoczesnych urządzeniach konsumenci mogą nie tylko wypłacić środki pieniężne, ale również m.in.:

- sprawdzić stan rachunku,

- zrealizować przelew,

- zrealizować przekaz pieniężny,

- zapłacić za rachunek,

- zakupić bilety komunikacji miejskiej,

- zmienić PIN,

- wypłacić środki pieniężne w walucie obcej (m.in. EUR, GBP, NOK, SEK),

- wpłacić darowiznę,

- wziąć kredyt gotówkowy,

- wpłacić środki pieniężne.

Ostatnia wymieniona usługa oferowana przez nowoczesne bankomaty (wpłata środków pieniężnych) spełnia oczekiwania klientów banków (rys. 7). Nowoczesne bankomaty są wyposażone w funkcję obiegową umożliwiającą wpłaty i wypłaty środków pieniężnych, co znacznie ułatwia dostęp konsumentów do wybranych usług bankowych, rozwijając tym samym sieć bankową w Polsce. W 2016 r. w bankomatach na terytorium Polski dokonano ponad 37,5 mln wpłat depozytów gotówkowych (w 2009 r. ponad 1,7 mln wpłat).

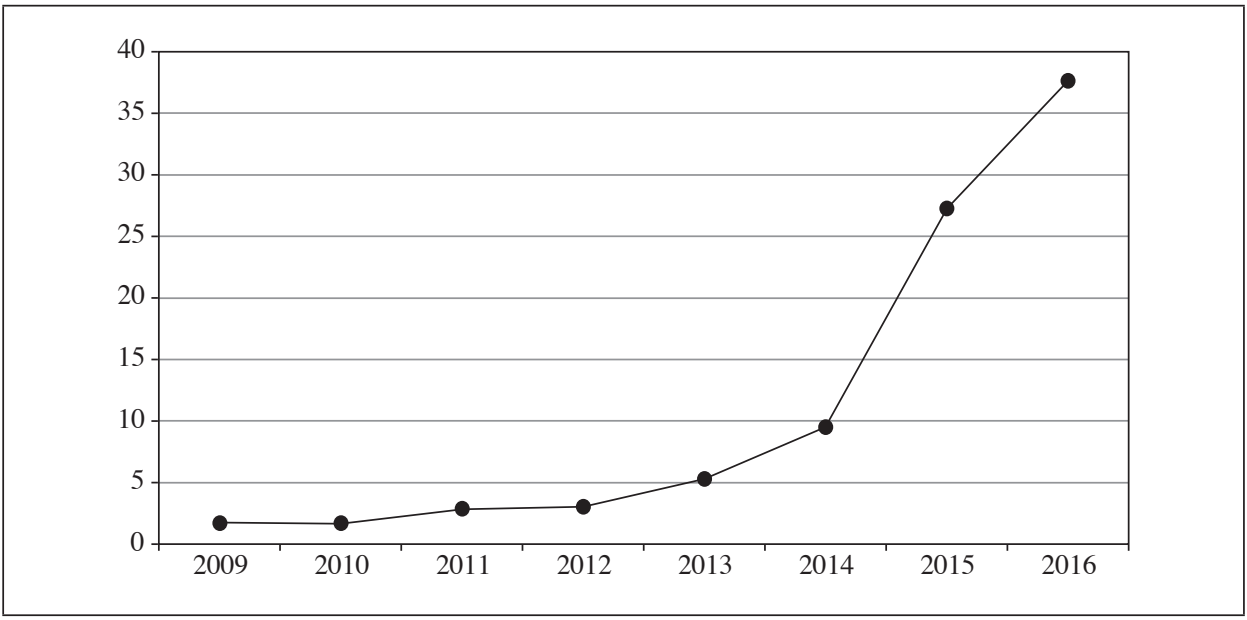

Rys. 7. Liczba depozytów gotówkowych złożonych w bankomatach w danym roku (w mln) Źródło: opracowanie własne na podstawie danych NBP. 
Tabela 1. Liczba użytkowników bankowości mobilnej w Polsce

\begin{tabular}{|l|c|c|c|c|c|c|}
\hline \multicolumn{1}{|c|}{ Bank } & 2012 & 2013 & 2014 & 2015 & 2016 & 03.2017 \\
\hline PKO BP SA & 236624 & 427542 & 625244 & 1328905 & 1652460 & 1774224 \\
\hline PEKAO SA & 201000 & 373063 & 595926 & 1014647 & 1495681 & 1616743 \\
\hline mBank SA & 300000 & 724096 & 892000 & 1092044 & 1327555 & 1387408 \\
\hline ING SA & 98000 & 244000 & 420146 & 500000 & 1048486 & 1188108 \\
\hline BZWBK SA & 124819 & 239000 & 483472 & 666278 & 974336 & 1017671 \\
\hline$\ldots$ & $\ldots$ & $\ldots$ & $\ldots$ & $\ldots$ & $\ldots$ & $\ldots$ \\
\hline Razem & 1192759 & 2470370 & 3330710 & 5720341 & 7687918 & 8265344 \\
\hline
\end{tabular}

Źródło: opracowanie własne na podstawie raportów prnews.pl.

Rozwój funkcji urządzeń, które umożliwiają konsumentom dostęp do wielu usług bankowych, powoduje dynamiczny i mniej kosztowny (dla banków) rozwój sieci bankowej w Polsce. Analizując rozwój bankowości mobilnej (tabela 1), można łatwo wskazać najbardziej dynamicznie rozwijający się kanał dystrybucji usług bankowych w zakresie funkcjonującej sieci bankowej. Liczba użytkowników bankowości mobilnej w Polsce w analizowanym okresie wzrosła o ponad $7 \mathrm{mln}$ użytkowników, jednoznacznie wskazując główny kierunek rozwoju sieci bankowej w Polsce.

\section{Przyszłość sieci bankowej w Polsce - rynek innowacji finansowych (FinTech)}

FinTech to sektor firm wykorzystujących nowoczesne technologie informatyczne w obszarze usług finansowych, który w ostatnim czasie dynamicznie rozwija się w polskim systemie finansowym. Jest to stosunkowo młoda branża, która w najbliższym czasie może znacząco wpłynąć na sektor finansowy. Fundamentem tego sektora jest technologia. Spółki FinTech oferują sprzedaż produktów finansowych przez internet; nie tworzą tradycyjnych oddziałów. Koszty ich działalności są w związku z tym nieporównywalnie niższe niż banków (Pacud 2016, s. 108-109). Firmy z sektora FinTech mają przewagę nad bankami, ponieważ są małe, „zwinne” i elastyczne. Dzięki dostępowi do kapitału banki mogą jednak wykorzystywać rozwiązania stosowane przez takie firmy i wdrażać je z sukcesem w swojej działalności (Szpringer 2017, s. 52).

Obserwując dynamiczny rozwój tego sektora, Komisja Nadzoru Finansowego podjęła próby identyfikacji tego rynku w celu przeprowadzenia działań na rzecz rozwoju innowacji finansowych (FinTech) w Polsce. W porozumieniu z Ministerstwem Finansów i Ministerstwem Rozwoju w grudniu 2016 r. powołano zespół 
roboczy, który miał za zadanie dokonać przeglądu obowiązujących przepisów prawa i regulacji nadzorczych w celu identyfikacji barier rozwoju tego rodzaju usług w Polsce. Co warte podkreślenia, zwrócono uwagę na fundamentalne znaczenie, jakie w dłuższej perspektywie ma bezpieczeństwo innowacji technologicznych dla trwałego rozwoju rynku usług finansowych. Zasugerowano, że najistotniejszym elementem rozwoju tego rynku jest wspieranie rozwiązań zapewniających przede wszystkim odpowiednie bezpieczeństwo oferowanych usług (Komunikat... 2016, s. 1).

Rozwiązania stosowane przez banki w Polsce na tle rozwiązań stosowanych przez inne europejskie sektory bankowe należy uznać za nowoczesne. Wysoko rozwinięta jest technologia w zakresie oferowania płatności kartami i płatności mobilnych, która dzięki swojemu zaawansowaniu może stanowić przykład dla krajów zachodnioeuropejskich. Dlatego też coraz częściej mówimy w Polsce o „,bankach FinTech” lub o „FinTechu w bankach”, a najbardziej innowacyjne banki postrzegają siebie jako część sektora FinTech (FinTech w Polsce... 2017, s. 9).

Wśród barier rozwoju innowacji finansowych w Polsce najczęściej wymieniane są:

- niejasne regulacje prawne,

- brak wiedzy cechujący potencjalnie zainteresowane podmioty o tym sektorze,

- brak polityki stymulacji rozwoju innowacji finansowych w Polsce,

- brak współpracy nadzoru z uczestnikami rynku,

- brak zachęt o charakterze fiskalnym.

Obecnie nie ma jednoznacznego stanowiska regulatorów rynku wobec sektora FinTech. Szczegółowej analizie prawnej powinny zostać poddane takie obszary, jak: blockchain i waluty wirtualne, przetwarzanie danych w chmurze czy crowdfunding. Istotne byłoby wprowadzenie regulacji i rekomendacji w tym zakresie. Co warte podkreślenia, w raportach zespołu ds. rozwoju innowacji finansowych wykazano, że firmy z sektora FinTech nie uważają banków za swoją bezpośrednią konkurencję (75\% ogółu odpowiedzi).

W rekomendacjach zespołu roboczego ds. rozwoju innowacji finansowych (FinTech w Polsce) zasugerowano liczne zmiany, których wdrożenie umożliwiłoby rozwój sieci bankowej w Polsce.

\section{Zakończenie}

Banki w Polsce i na całym świecie czeka zmiana strategii funkcjonowania na rynku (zwłaszcza w zakresie sprzedaży usług bankowych). Zmieniające się preferencje klientów wymuszają na bankach procesy dostosowawcze, które wpływają 
na organizację sieci bankowej. W najbliższym czasie ograniczana będzie liczba oddziałów bankowych. Jest to spowodowane przede wszystkim zapotrzebowaniem rynku (konsumentów) oraz ograniczaniem kosztów działalności bankowej. Rozwój rynku kart płatniczych i funkcji oferowanych przez bankomaty umożliwia bankom dywersyfikację kanałów dystrybucji usług bankowych. Nowoczesny sposób korzystania z podstawowych usług bankowych przez bankowość elektroniczną stwarza duże możliwości rozwoju innowacji finansowych oferowanych przez rynek FinTech, który będzie w znacznym stopniu kreował sieć bankową w Polsce w najbliższym czasie.

\section{Literatura}

Bank $i$ agent bankowy (2017), red. J. Cichorska, Difin, Warszawa.

Boguski J. (2016), Marketing innowacji, Oficyna Graficzno-Wydawnicza Typografika, Warszawa.

Capiga M. (2015), Bezpieczeństwo transakcji finansowych w Polsce, Wydawnictwo CeDeWu.pl, Warszawa.

Dembinski P. (2011), Finanse po zawale, Studio Emka, Warszawa.

Elementy nauki o finansach. Kategorie i instrumenty finansowe (2007), red. K. Jajuga, Wydawnictwo PWE, Warszawa.

Finanse osobiste (2016), red. R. Milic-Czerniak, Difin, Warszawa.

FinTech w Polsce bariery i szanse rozwoju (2017), http://fintechpoland.com/wp-content/ uploads/2016/12/FinTech_w_Polsce_bariery_i_szanse_rozwoju.pdf (data dostępu: 30.08.2017).

Flejterski S. (2007), Metodologia finansów, Wydawnictwo Naukowe PWN, Warszawa.

Grzegorczyk W., Krawiec W., Sibińska A. (2010), Współczesne dylematy marketingu bankowego, Wydawnictwo Uniwersytetu Łódzkiego, Łódź.

Komunikat w sprawie spotkania Kierownictwa Urzędu KNF z przedstawicielami Ministerstwa Finansów oraz Ministerstwa Rozwoju dotyczącego podjęcia działań na rzecz rozwoju innowacji finansowych (FinTech) w Polsce (2016), https://www.knf.gov.pl/ dla_rynku/fin_tech/komunikaty?articleId=48862\&p_id=18 (data dostępu: 30.08 .2017 ).

Krzyścin M. (2013), Reklama produktów i usług bankowych, Wydawnictwo CeDeWu.pl, Warszawa.

Liberska B. (2016), Nowa globalna architektura finansowa, Wydawnictwo Uniwersytetu Jagiellońskiego, Kraków.

Mirabile I., Pieber M.K., Sauri L., Stril A. (2015), Protecting the Drugs of Tomorrow, „Competition Merger Brief”, nr 2.

Pacud R. (2016), Bank $i$ agent bankowy, Difin, Warszawa.

Szpringer W. (2017), Nowe technologie a sektor finansowy, Poltext, Warszawa.

Ustawa z dnia 29 sierpnia 1997 r. - Prawo bankowe (1997), Dz.U. nr 140, poz. 939.

Zarzqdzanie ryzykiem bankowym (2012), red. M. Iwanicz-Drozdowska, Wydawnictwo Poltext, Warszawa. 


\section{Traditional and Modern Forms of Building a Banking Network - the Case of Poland}

(Abstract)

The article analyses trends and the level of traditional and modern methods of building a banking network in Poland. The development of technologies, modern access channels to banking services, as well as the promotion of non-cash transactions in Poland favours the development of not only the infrastructure of a banking system focused on reducing operating costs, but also financial innovations (FinTech). Banks both in Poland and globally are waiting for a change in banking market strategy, especially as regards sales of banking services. The changing preferences of bank customers have been brought about by adaptation processes that have a significant impact on the organisation of the banking network. In the near future, the number of bank branches and ATMs will be limited, mainly due to the response to market demand (consumers) as well as the falling costs of banking. The development of the payment card market and modern forms of payment allows banks to diversify the distribution channels of banking services. Changing regulations (including the PSDII directive) also creates broad possibilities for the development of financial innovations offered by the FinTech market. That market will go a long way to expanding the banking network in Poland in the near future.

Keywords: banking network, financial innovation, payment cards, FinTech sector. 